\title{
E CHEGAMOS AOS QUARENTA
}

A Sociedade Brasileira de Química (SBQ) completa 40 anos, orgulhosa das ações que a trouxeram até aqui e com plena consciência da sua responsabilidade futura e dos desafios a serem vencidos nos próximos quarenta anos. Uma Sociedade jovem, quando globalmente comparada com algumas coirmãs, mas ao mesmo tempo tão plena de realizações! Em seu curto período de existência a SBQ teve participação ativa em todos os grandes movimentos relacionados à educação, ciência e tecnologia no Brasil, se tornando a grande interlocutora nacional nas questões envolvendo diferentes aspectos da Química. Nesses quarentas anos a SBQ acompanhou pró-ativamente o desenvolvimento do país, a criação de um sistema robusto e menos centralizado de ciência, tecnologia e inovação (CT\&I), a expansão das universidades e centros de pesquisa e a consolidação de cursos de graduação e programas de pós-graduação, em consonância com uma verdadeira revolução científica em nível global, que resultou na chamada "era tecnológica" que ora vivemos. Nesse período as publicações da SBQ consolidaram-se e profissionalizaram-se, podendo ser acessadas de forma integrada através de um grande portal que reúne toda a atividade editorial da SBQ (PubliSBQ). Além disso, as Reuniões Anuais transformaram-se em atividade quase que obrigatória dentro do extenso calendário associado à Química brasileira.

Uma das ações pioneiras da recém-nascida SBQ foi a criação da sua primeira revista, a Química Nova, que se tornou referência perante a comunidade química brasileira, e que hoje lança esse número especial comemorativo de aniversário. Esse número especial foi concebido visando a contextualização de aspectos relevantes decorrentes da presença da SBQ na Química brasileira. A evolução da Química enquanto ciência é analisada pelo viés das diferentes divisões científicas da SBQ, em artigos assinados pelos atuais diretores da gestão 2016-2018, que tiveram liberdade para escolher coautores. Além disso, diferentes facetas relacionadas à pós-graduação, à relação com a indústria e à forma de comunicação da SBQ com a comunidade são abordadas, levantando um panorama interessante da realidade atual, e fornecendo um alicerce sobre o qual se pode planejar o crescimento para os próximos anos. Cada autor recebeu a mesma carta-convite, explicando os objetivos e o que se esperava de sua contribuição. Os artigos correspondem à leitura que cada um fez dessa carta-convite, e não sofreram nenhum tipo de padronização ou interferência dos editores, exceto a solicitação de enxugamento nos poucos casos em que a submissão original ultrapassou o limite de páginas inicialmente estipulado. Como poderá ser verificado, os artigos apresentam uma grande heterogeneidade em enfoque $\mathrm{e}$ estilo, e representam muito bem a pluralidade da nossa SBQ.
Várias ações vêm sendo realizadas pela Diretoria e Conselho da SBQ para celebrar esses quarenta anos, e outras ainda estão planejadas até o final de 2017. Além da Química Nova, a Revista Virtual de Química (RVQ) e o Journal of the Brazilian Chemical Society (JBCS) também prepararam edições comemorativas dos 40 anos da SBQ: a RVQ abordando a temática das biomassas brasileiras, e o JBCS, através de uma edição reunindo artigos originais de jovens pesquisadores. O lançamento desse número especial de Química Nova ocorre concomitantemente à $40^{\mathrm{a}}$ Reunião Anual da SBQ, que será em conjunto com o $46^{\circ}$ Congresso Mundial de Química da IUPAC, realizado pela primeira vez na América do Sul. A realização do congresso da IUPAC no Brasil é fruto de um trabalho intenso das quatro últimas gestões da nossa sociedade, com o objetivo principal de presentear seu associado com um evento de proporções à altura da comemoração.

Neste momento comemorativo é oportuno também refletir sobre os rumos da nossa sociedade. A glória do passado não é garantia do seu futuro, cujo sucesso depende de várias novas ações no presente. É preciso reconhecer que a expansão trouxe uma mudança qualitativa na comunidade química brasileira, hoje representada por um grande contingente de jovens que não possuem vínculos históricos com a SBQ. O sucesso dos próximos anos dependerá de ações que equilibrem a tradição representada pelos fundadores da SBQ e dos seus primeiros sócios (a maioria dos quais ainda está ativa e representa o maior patrimônio da nossa sociedade), que artesanalmente construíram a SBQ com trabalho em equipe, e os anseios de uma geração que nasceu na era da informática e da tecnologia, e naturalmente vislumbra uma forma diferente de representação; de ações que reconheçam e mensurem as diferenças regionais; de ações que conscientizem a comunidade da força e da representatividade da SBQ; e da continuidade nas ações que colocam a SBQ na linha de frente da batalha por uma educação de qualidade e um sistema de C,T\&I compatíveis com a grandeza do Brasil.

Os editores desse número especial agradecem a Diretoria e Conselho da SBQ pelo convite, e a cada um dos autores pelo trabalho.

Uma boa leitura a todos, e que venham os próximos quarenta.

Susana I. C. Torresi Maria D. Vargas Aldo J. G. Zarbin 